\title{
KETERKAITAN CITRA MEREK DAN HARGA TERHADAP KEPUTUSAN PEMBELIAN PADA EMAK DI FRIED CHICKEN PELAIHARI
}

\author{
Ines Saraswati Machfiroh \\ Program studi Akuntansi, Politeknik Negeri Tanah Laut \\ E-mail : inessaraswati.m@gmail.com
}

\begin{abstract}
Abstrak
Beragam faktor akan saling berkaitan untuk mempengaruhi konsumen dalam mempercayakan tempat berbelanja. Citra merek yang baik dapat dijadikan kekuatan oleh berbagai perusahaan untuk menarik konsumen, sedangkan harga produk yang murah dan terjangkau dengan daya beli konsumen pun akan berkaitan untuk mempengaruhi keputusan pembelian konsumen tersebut. Penelitian ini bertujuan untuk mengetahui keterkaitan citra merek dan harga terhadap keputusan pembelian pada EMAK DI Fried chicken. Populasi dalam penelitian ini adalah seluruh konsumen EMAK DI Fried chicken tetapi tidak diketahui jumlah pastinya. Pengumpulan data menggunakan metode observasi dan angket. Sampel yang diambil adalah 50 orang berdasarkan metode random sampling. Analisis data menggunakan metode kualitatif dan kuantitatif. Dari hasil analisis data diketahui bahwa kategori citra merek menyatakan baik dan kategori harga menyatakan murah. Serta kategori keputusan pembelian menyatakan tinggi. Variabel citra merek dan harga berpengaruh terhadap keputusan pembelian. Berdasarkan hasil penelitian menyatakan bahwa semakin baik citra merek dan manajemen pelayanan, serta semakin murah harga yang ditawarkan maka dapat meningkatkan keputusan pembelian.
\end{abstract}

Kata kunci: citra merek, kualitas produk, harga, keputusan pembelian

\section{Abstract}

Various factors will be interrelated to influence consumers in entrusting shopping. A good brand image can be used as a force by various companies to attract consumers, while the price of cheap and affordable products with consumer purchasing power will also be related to influencing consumer purchasing decisions. This study aims to determine the relationship between brand image and price of purchasing decisions on EMAK DI Fried chicken. The population in this study were all consumers of EMAK IN Fried chicken but the exact number is unknown. Data collection uses observation and questionnaire methods. The sample taken was 50 people based on the random sampling method. Data analysis using qualitative and quantitative methods. From the results of data analysis it is known that the brand image category states well and the price category states cheap. As well as the purchase decision category stated high. Variable brand image and price influence on purchasing decisions. Based on the results of the study stated that the better the brand image and service management, and the cheaper the price offered, it can increase purchasing decisions.

Keywords: brand image, product quality, price, purchasing decision

\section{PENDAHULUAN}

Segala sesuatu yang berhubungan dengan manusia setiap kali akan mengalami perubahan, baik dalam bidang politik, ekonomi, sosial, maupun pola perilaku dan budaya. Salah satunya adalah perkembangan kuliner dewasa ini yang begitu cepat. Berbagai restoran, depot, maupun rumah makan berkembang dengan sangat pesat sehingga membuat persaingan semakin ketat.

Sejalan dengan banyaknya jumlah tempattempat makan di Indonesia khususnya di Pelaihari menyebabkan konsumen mempunyai banyak alternatif pilihan berbelanja atau dapat dikatakan sulit dalam menentukan keputusan pembelian. Keputusan pembelian merupakan fungsi pe-masaran yang penting karena mampu mem-berikan keuntungan bagi perusahaan.

Masing-masing perusahaan harus memiliki strategi untuk memenangkan konsumen dan dapat bertahan di tengah ketatnya persaingan. Nilai (value) dan kualitas akan berpengaruh lebih sensitif terhadap harga.

Konsumen cenderung menjadikan citra merek (brand image) sebagai acuan sebelum 
melakukan pembelian suatu produk/jasa. Maka, perusahaan harus mampu menciptakan citra merek yang menarik sekaligus menggambarkan kelebihan produk yang sesuai dengan keinginan dan kebutuhan konsumen sehingga dengan demikian konsumen memiliki citra yang positif terhadap merek. Harga adalah segala bentuk biaya moneter yang dikorbankan oleh konsumen dan merupakan salah satu variabel yang sangat penting dalam perilaku bisnis. Harga produk yang murah dan terjangkau dengan daya beli konsumen akan memengaruhi keputusan konsumen tersebut. Harga yang terjangkau akan lebih meningkatkan keinginan konsumen untuk selalu membeli produk yang ditawarkan.

EMAK DI Fried chicken adalah satu restoran cepat saji yang menjual sejumlah besar produk kuliner berbahan baku ayam. Adapun keberadaan EMAK DI Fried chicken sebagai salah satu restoran yang ada di Pelaihari diharapkan dapat memberikan pertimbangan mengenai keterkaitan citra merek dan harga terhadap keputusan pembelian.

Di bawah ini disajikan data mengenai jumlah pendapatan kotor selama kurun waktu 5 bulan dari bulan Oktober sampai dengan bulan Februari tahun 2018.

TABEL 1 JUMLAH PENDAPATAN KOTOR

\begin{tabular}{|c|c|c|c|}
\hline Bulan & $\begin{array}{c}\text { Pendapatan } \\
\text { Kotor (Rp) }\end{array}$ & $\begin{array}{c}\text { Penurunan/ } \\
\text { Peningkatan } \\
(\mathrm{Rp})\end{array}$ & Persentase \\
\hline Okt & 55.000 .000 & - & - \\
\hline Nov & 45.000 .000 & $(10.000 .000)$ & $18,18 \%$ \\
\hline Des & 40.000 .000 & $(5.000 .000)$ & $11,11 \%$ \\
\hline Jan & 47.000 .000 & 7.000 .000 & $17,50 \%$ \\
\hline Feb & 75.000 .000 & 28.000 .000 & $59,57 \%$ \\
\hline
\end{tabular}

Dari data di atas dapat dilihat bahwa telah terjadi penurunan pendapatan sebesar 18,18\% pada bulan November dan $11,11 \%$ pada bulan Desember. Sedangkan pada bulan-bulan berikut-nya jumlah pendapatan kotor mulai meningkat. Persoalannya saat ini adalah peningkatan persentase pendapatan kotor tersebut terlalu signifikan.

Pengkajian dilakukan terbatas pada penyebab yang berkaitan dalam mempengaruhi keputusan pembelian antara lain citra merek dan harga. Tujuannya adalah menganalisis besarnya keterkaitan masing-masing yaitu citra merek dan harga terhadap keputusan pembelian tersebut.

Sebagaimana kita ketahui, menurut Tjiptono (2011: 112) citra merek (brand image) merupakan bentuk holistik untuk semua asosiasi merek yang berkaitan dengan keyakinan konsumen terhadap merek tertentu. Citra dapat didasarkan pada kenyataan atau fiksi tergantung presepsi yang terkait. Representasi dari keseluruhan persepsi terhadap merek dan dibentuk dari informasi dan pengalaman masa lalu. Konsumen yang memiliki citra yang positif terhadap suatu merek, akan lebih memungkinkan untuk melakukan pembelian.

Citra merek mengacu pada skema memori akan sebuah merek, yang berisikan interpretasi konsumen atas atribut, kelebihan, penggunaan, situasi, para pengguna, dan karakteristik pemasar dan/atau karakteristik pembuat dari produk/merek tersebut. Citra merek adalah apa yang konsumen pikirkan dan rasakan ketika mendengar atau melihat nama suatu merek.

Image konsumen yang positif terhadap suatu brand lebih memungkinkan konsumen untuk melakukan pembelian. Brand yang lebih baik juga menjadi dasar untuk membangun citra perusahaan yang positif. Merek yang kuat dapat menarik konsumen untuk menggunakannya. Sebagai faktor penentu dalam pemilihan keputusan pembelian, sedangkan syarat yang kuat adalah citra merek (brand image). Citra merek merupakan interprestasi akumulasi berbagai informasi yang diterima konsumen. Yang menginterpretasikan adalah konsumen dan yang diinterpretasikan adalah informasi. Hasil interpresentasi bergantung pada dua hal, yaitu bagaimana konsumen melakukan interpresentasi dan informasi apa yang diinterpresentasikan. Citra merek terdiri dari dua faktor utama yaitu: 
1) Faktor fisik, merupakan karakteristik fisik dari merek tersebut, seperti desain, kemasan, logo, nama merek, fungsi, dan kegunaan produk dari merek itu.

2) Faktor psikologis, dibentuk oleh emosi, kepercayaan, nilai dan kepribadian yang dianggap oleh konsumen dapat menggambarkan produk dari merek tersebut. Citra merek sangat erat kaitannya dengan apa yang orang pikirkan dan rasakan terhadap suatu merek tertentu, sehingga dalam citra merek faktor psikologis lebih banyak berperan dibandingkan faktor fisik merek tertentu.

Harga merupakan jumlah semua nilai yang diberikan oleh pelanggan untuk mendapatkan keuntungan dari memiliki atau menggunakan suatu produk atau jasa (Philip Kolter, 2008 : 345). Harga itu bersifat fleksibel, artinya dapat disesuaikan dengan cepat. Dari empat unsur bauran pemasaran tradisional, harga adalah elemen yang paling mudah diubah dan diadaptasikan dengan dinamika pasar. Ini terlihat jelas dari persaingan harga (perang diskon) yang kerap terjadi dalam dunia bisnis. Harga memainkan peranan penting bagi perekonomian secara makro, konsumen, dan perusahaan.

a) Bagi perekonomian, harga merupakan regulator dasar dalam sistem perekonomian karena harga berpengaruh terhadap alokasi faktor-faktor produksi seperti tenaga kerja, tanah, modal, dan kewirausahaan.

b) Bagi konsumen, dalam dunia bisnis, ada segmen pembeli yang sangat sensitif terhadap faktor harga (menjadikan harga sebagai satu satunya pertimbagan membeli produk) dan ada pula yang tidak.

c) Bagi perusahaan, dibandingkan dengan bauran pemasaran lainnya (produk, distribusi dan promosi) yang membutuhkan pengeluaran dana dalam jumlah besar, harga merupakan satu-satunya elemen bauran pemasaran yang mendatangkan pendapatan.

Keputusan Pembelian Perilaku Konsumen merupakan tindakan yang secara langsung terlibat dalam usaha memperoleh, menentukan produk dan jasa, termasuk proses pengambilan keputusan yang mendahului dan mengikuti tindakantindakan tersebut. Dari pengertian ini dapat diketahui bahwa pemahaman terhadap perilaku konsumen bukanlah pekerjaan yang mudah, tetapi cukup sulit dan kompleks, khususnya disebabkan oleh banyaknya variabel yang mempengaruhi dan variabel-variabel tersebut cenderung saling berinteraksi. Tahap-tahap proses keputusan pembelian menurut Philip Kotler (2008:179) adalah sebagai berikut:

1) Pengenalan masalah

Proses pembelian dimulai dengan pengenalan masalah atau kebutuhan. Kebutuhan itu dapat digerakkan oleh rangsangan dari dalam atau dari luar pembeli.

2) Pencarian informasi

Konsumen dapat memperoleh informasi dari berbagai sumber, meliputi :

a) Sumber pribadi : keluarga, teman, tetangga, kenalan.

b) Sumber komersil : iklan, tenaga penjual, penyalur, kemasan, pameran.

c) Sumber publik : media massa, organisasi konsumen.

d) Sumber eksperensal : pernah menangani, menguji dan menggunaksn produk tersebut.

3) Evaluasi alternatif

Dalam tahap ini tidak ada suatu proses evaluasi yang mudah dan tunggal yang dapat dipergunakan untuk semua konsumen atau bahkan oleh seorag konsumen dalam semua situasi pembeliannya.

4) Keputussan pembelian

Tahap ini diawali dengan tahap penilaian berbagai alternatif yang dapat dilihat dari atribut-atribut yang melekat pada produk itu. Dengan indikasi itu konsumen membentuk pilihan. Namun ada dua faktor yang mempengaruhi pada saat memilih, yaitu sikap pada orang lain dan kejelekan suatu produk.

5) Perilaku setelah pembelian

Setelah membeli suatu produk, konsumen akan mengalami beberapa tingkat kepuasan atau ketidakpuasan. 


\section{METODE PENELITIAN}

Metode penelitian yang digunakan yaitu :

1. Observasi

Bertujuan untuk mengamati dan mencatat pengumpulan data secara langsung. Data yang digunakan dalam penelitian ini adalah data tahun 2018 .

2. Angket

Kumpulan pertanyaan tertulis yang digunakan untuk memperoleh informasi dari responden. Responden yang dijadikan sampel dalam penelitian ini adalah para konsumen EMAK DI FRIED CHICKEN yang diambil secara acak berjumlah 50 orang. Penyebaran angket ini dilakukan pada saat konsumen datang untuk membeli ke EMAK DI FRIED CHICKEN dan dialkukan selama 3 bulan.

\section{Perkiraan Sederhana}

Sebagai dasar proses menganalisa data dengan peralatan sederhana untuk mendapatkan perkiraan hasil data.

4. Analisis Kualitatif

Menganalisis data yang tidak ada hubungannya dengan angka-angka. Penyajiannya berupa keterangan, penjelasan, serta pembahasan secara tertentu.

5. Analisis Kuantitatif

Menganalisis data yang berhubungan dengan angka-angka. Penyajiannya berupa perhitungan data statistik dengan menggunakan aplikasi.

\section{HASIL}

Dari hasil penelitian, citra merek EMAK DI Fried chicken masuk ke dalam kategori baik. Variabel citra merek mempunyai keterkaitan terhadap variabel keputusan pembelian, dengan hasil angket sebesar 18/50 atau setara dengan $36 \%$.

Dari hasil penelitian, harga yang ditetapkan EMAK DI Fried chicken masuk ke dalam kategori murah. Variabel harga mempunyai keterkaitan terhadap variabel keputusan pembelian, dengan hasil angket sebesar 32/50 atau setara dengan $64 \%$.

Hal ini menunjukan bahwa konsumen cenderung lebih sensitif terhadap harga daripada citra merek ketika memutuskan melakukan pembelian.

\section{PEMBAHASAN}

Berdasarkan hasil penelitian ini, dapat dibuktikan bahwa adanya keterkaitan variabel citra merek dan harga terhadap keputusan pembelian adalah benar. Menurut Tjiptono (2011:112) citra merek (brand image) merupakan bentuk holistik untuk semua asosiasi merek yang berkaitan dengan keyakinan konsumen terhadap merek tertentu. Pembentukan citra yang baik dapat dijadikan sebagai kekuatan oleh perusahaan untuk menarik konsumen potensial dan mempertahankan pelanggan yang ada. Persepsi yang positif akan membentuk brand image yang positif juga. Konsumen cenderung menjadikan brand image sebagai acuan sebelum melakukan pembelian suatu produk/jasa. Maka, perusahaan harus mampu menciptakan brand image yang menarik sekaligus menggambarkan manfaat produk yang sesuai dengan keinginan dan kebutuhan konsumen sehingga dengan demikian konsumen memiliki citra yang positif terhadap merek.

Dari hasil penelitian, citra merek EMAK DI Fried chicken masuk ke dalam kategori baik. Variabel citra merek mempunyai keterkaitan terhadap variabel keputusan pembelian, dengan hasil angket sebesar 18/50 atau setara dengan $36 \%$.

Menurut Philip Kolter (2008:345) Harga merupakan jumlah semua nilai yang diberikan oleh pelanggan untuk mendapatkan keuntungan dari memiliki atau menggunakan suatu produk atau jasa. Kemudian harga itu bersifat fleksibel yang berarti bisa disesuaikan dengan cepat. Ini terlihat jelas dari persaingan harga yang kerap terjadi dalam industri ritel.

Dari hasil penelitian, harga yang ditetapkan EMAK DI Fried chicken masuk ke dalam kategori murah. Variabel harga mempunyai keterkaitan terhadap variabel keputusan pembelian, dengan hasil angket sebesar 32/50 atau setara dengan $64 \%$. 
Hal ini menunjukan bahwa konsumen cenderung lebih sensitif terhadap harga daripada citra merek ketika memutuskan melakukan pembelian.

Dapat disimpulkan bahwa terdapat keterkaitan yang erat antara faktor citra merek, harga dan keputusan pembelian. Dengan meningkatkan citra merek dan menentapkan harga yang murah kepada konsumen akan memberikan dampak positif kepada keputusan pembelian.

Jika ketiga faktor itu bersinergi secara seimbang maka restoran cepat saji EMAK DI Fried chicken akan mendapatkan konsumen yang memiliki keputusan pembelian yang tinggi terhadap perusahaan.

\section{KESIMPULAN}

1. Citra merek pada restoran cepat saji EMAK DI Fried chicken berdasarkan hasil penelitian menunjukkan bahwa sebagian besar responden (rata-rata 3,68) menyatakan citra merek baik. Namun, masih ada beberapa konsumen yang menyatakan bahwa merek EMAK DI Fried chicken tidak baik, dikarenakan kurang terciptanya kenyamanan yang di rasakan konsumen.

2. Harga yang ditetapkan EMAK DI Fried chicken berdasarkan hasil penelitian menunjukan bahwa sebagian besar responden (rata-rata 4,28) menyatakan bahwa harga sangat murah. Hal ini dikarenakan EMAK DI Fried chicken menawarkan harga yang sesuai dengan daya beli masyarakat, harga yang ditawarkan lebih murah dibanding restoran cepat saji lain, dan harga sesuai dengan kualitas produk.

3. Keputusan pembelian pada EMAK DI Fried chicken berdasarkan hasil penelitian menunjukkan bahwa sebagian besar responden (rata-rata 3,10) adalah tinggi. Namun, masih ada konsumen yang memberikan keputusan pembelian pada EMAK DI Fried chicken rendah, dikarenakan keengganan konsumen untuk berbelanja saat situasi sangat ramai dan apabila produk yang dibeli bisa dibuat sendiri di rumah.

4. Berdasarkan hasil penelitian, citra merek terhadap keputusan pembelian berkaitan dan berpengaruh positif, artinya apabila citra merek semakin baik maka keputusan pembelian juga akan meningkat, begitu pula sebaliknya. Nilai angket menunjukkan bahwa citra merek memiliki tingkat keterkaitan yang lemah terhadap keputusan pembelian yaitu sebesar 18/50 atau setara dengan $36 \%$.

5. Berdasarkan hasil penelitian, harga terhadap keputusan pembelian berkaitan dan berpengaruh positif, artinya apabila harga semakin murah maka keputusan pembelian juga akan meningkat, begitu pula sebaliknya. Nilai angket menunjukkan bahwa harga memiliki tingkat keterkaitan yang baik terhadap keputusan pembelian sebesar 32/50 atau setara dengan $64 \%$.

6. Diperlukan penelitian lebih lanjut mengenai keterkaitan faktor-faktor lain yang dapat mempengaruhi keputusan pembelian.

\section{DAFTAR PUSTAKA}

Euis Soliha. 2008. Analisis Industri Ritel di Indonesia. Jurnal Bisnis dan Ekonomi 15(2): 128-142. dalam http://www.unisbank.ac,id/. Diunduh pada 26 September 2018

Hurriyati, Ratih. 2005. Bauran Pemasaran dan Loyalitas Konsumen. Bandung: Alfabeta

Kotler, Philip. 2003. Manajemen Pemasaran edisi Kesebelas. Jakarta: Gramedia

Simamora, Bilson. 2003.Aura Merek. Jakarta: PT.Ikrar Mandiri Abadi

Susanto, AB dan Himawan Widjanarko.2004. Power Branding. Jakarta: Quantum Bisnis dan Manajemen

Kuncoro, Mudrajat. 2003. Metode Riset untuk Bisnis dan Ekonomi. Bagaimana Meneliti dan Menulis Tesis. Jakarta: Erlangga. 
Kamus Umum Bahasa Indonesia. Pusat Bahasa Departemen Pendidikan Nasional. Edisi Ketiga. Balai Pustaka.

Sekaran, Uma. 2006. Research Methods for Business. Metodologi Penelitian untuk Bisnis. Jakarta: Salemba. 